agora (ruang publik) untuk saling bertemu di pasar, kebutuhan cakap bicara, kebutuhan religi hingga ke cita-cita memperbaiki diri dalam hidup bersama (politik) sebagai warga negara dan membangun negara kultural.

Dialog dan tragedi kehidupan diawali ketika bersentuhan dengan kebudayan yang harus dipahami apabila kita memiliki kesadaran diri secara total sehingga kerancuan dan penyeragaman budaya dapat dihindari. Ketika pemahaman akan ekspresi estetis hingga kritik estetika kebudayaan, maka humanisme dibicarakan. Manusia menjadi sadar ketika ia berpuisi, ia pun berada dalam sebuah ruang yang konkret sekaligus ruang batinnya. Ruang batin mengajak kita untuk merenungkan filsafat dan sastra (serta belajar menulis puisi) serta masyarakat seni di Indonesia. Agaknya hal itu belumlah cukup bagi Mudji Sutrisno karena ia harus merefleksikan Yunani melalui puisi dan goresan sketsanya, dan akhirnya tulisan dari kawan-kawannya tentang apa yang telah dilakukannya menjadi penutup dari bukunya.

Buku yang sangat padat dan seakan menjadi perjalanan eksistensi penulisnya memang menawarkan perjalanan kehidupannya yang beragam, dari filsuf, pecinta seni, hingga humanis. Sketsa perjalanan yang dialaminya dan terkesan terorientasi ke Yunani dituangkannya dalam bahasa puitis, metaphoris, simbolis, dan menjadi "terganggu" ketika sketsa humanisme tersebut dipenggal dengan adanya teori estetika dan seni lengkap dengan bagannya. Meskipun demikian buku Oase Estetis tetap menarik, terutama bagi masyarakat pecinta dan pengamat budaya, seni, atau siapa saja yang tertarik untuk memahami keindahan humanisme yang bersumber dari wacana dan pengalaman empiris manusianya yang diolah secara filosofis.

Irmayanti M. Budianto

Pengajar Program Studi Filsafat, Fakultas Ilmu Pengetahuan Budaya,

Universitas Indonesia

\title{
Perjalanan Hidup dan Kreativitas Seni Pengrawit Unggulan
}

Darsono. Pengrawit Unggulan Luar Tembok Keraton. Cet. I. (Surakarta: Yayasan Citra Etnika, 2002); xxiii + 284 halaman.

Pengrawit Unggulan Luar tembok Keraton diterbitkan oleh Citra Etnika Surakarta pada tahun 2002, diberi Kata Pengantar oleh Rahayu Supanggah, dan diedit oleh Kundharu Sabdhono. Buku ini terdiri atas lima bab: Bab I 
"Keraton Surakarta dan Karawitan"; Bab II "Perkumpulan Karawitan Luar Tembok Keraton"; Bab III "Perjalanan Hidup Cokrodiharjo dan Sunarto Cipto Suwarso"; Bab IV "Kehidupan Karawitan Luar Tembok Keraton"; dan Bab V "Penutup".

Penulis buku ini Darsono adalah seorang praktisi dan seniman akademik. Buku ini mengungkap latar belakang kehidupan dua seniman, yaitu Cokrodihardjo dan Sunarto Cipto Suwarso sejak kanak-kanak hingga menjadi pengrawit unggulan dan disegani (hlm.vii). Sebagai pekerja seni, dalam hal ini pengrawit, mereka selalu menunjukkan ketekunan dan keuletan ketika menggarap suatu gending dan kemudian mementaskannya dalam pelbagai kesempatan. Dalam perjalanan hidup sebagai pengrawit, mereka senantiasa berusaha mempelajari, memperhatikan, dan mengolah (kemampuan, pengetahuan) ngelmu dari pengrawit lain yang mereka pandang sebagai tokoh idola serta mengakomodasi jenis kesenian lain (hlm.viii). Kreativitas dalam mengolah gending menjadikan ciri khas mereka sehingga sebagai penabuh/ penyaji mereka dikenal juga sebagai pelatih dan pencipta (gending) karawitan. Di dalam buku ini juga dibahas sekelumit latar kesejarahan sebagai pengantar kepada bahasan inti, yaitu biografi dua pengrawit dan karyanya.

Sejak Perjanjian Giyanti yang membagi wilayah kerajaan Mataram menjadi dua: keraton Surakarta dan Yogyakarta), timbulah "fanatisme" kewilayahan akibat pengaruh dari kedua pusat kekuasaan itu. Berdasarkan catatan Haitingh dalam Sekitar Jogjakarta 1755--1825, Perjanjian GiantiPangeran Dipanegara (Soekanto, Djakarta, Mahabharata, 1925, hlm. 21), yang dikutip oleh Prapto Yuwono dalam bukunya Sistem Hukum Jawa Abad ke-18 (Jakarta, Wedatama Widya Sastra, 2003, hlm.11--12), perjanjian tersebut ditandatangani di desa Giyanti atau Jatisari pada tanggal 13 Februari 1755 oleh Sunan Surakarta (Pakubuwana III) dan Sultan Yogyakarta (P. Mangkubumi/ Hamengkubuwana I), setiap pihak mendapatkan daerah di wilayah Jawa Tengah dan Jawa Timur, yaitu untuk Sunan Surakarta: Jagaraga, Panaraga, separuh Pacitan, Kediri, Blitar (termasuk Srengat dan Lodaya), Pace (termasuk Nganjuk dan Brebek), Wirasaba (Maja Agung), Blora, Banyumas Untuk Sultan Yogyakarta: Kedawung dan Madiun, Magetan, Caruban, separo Pacitan, Kertasana, Kalangbret, Ngrawa (termasuk Tulungagung), Japan (Majakerta), Jipang (Bojanegara), Teras Karas, Sela, Warung (Kuwu Wirasari) dan Grobogan. Peristiwa pembagian wilayah kekuasaan tidak berhenti sampai di situ, pada babak berikutnya, dua tahun kemudian, pada bulan Februari 1757, di Salatiga, diselenggarakan perjanjian antara Sunan Surakarta, Sultan Yogyakarta (yang diwakili oleh patih Danureja) dan Gubernur Haitingh, memberikan kepada Mas Said (Mangkunegara I) tanah/bumi Kedawung, Laroh, Matesih, dan Gunung Kidul. Akhirnya, pada tahun 1812,Yogyakarta terbagi menjadi dua wilayah, yaitu Kasultanan dan Pakualaman.

Keraton pada saat itu dipandang sebagai pusat kekuasaan sekaligus pusat pelestarian, pengembangan, dan pembinaan kebudayaan sehingga keempatnya berusaha untuk menghasilkan karya yang berbeda-beda sesuai dengan ideologi yang dianut dan dikembangkannya. Keraton merupakan 
pusat kosmos dan raja dipandang sebagai wakil Tuhan di dunia. Berhubungan dengan itu, semua seniman/budayawan keraton berkarya, baik dipesan maupun tidak, untuk persembahan kepada raja.

Produk budaya yang dihasilkan oleh keempat pusat keraton tersebut di samping adat-istiadat juga kesenian, seperti wayang, karawitan, tari, batik, keris/tosan aji, tembang/macapat. Berbagai macam produk budaya ini dirawat dan dikembangkan oleh masing-masing. Kesenian di keraton harus tunduk (terikat) pada aturan, tatanan, norma, konvensi, hukum yang dianutnya. Sebaliknya, kesenian di luar keraton cenderung bersifat bebas namun bertanggung jawab, tidak terikat karena tidak mengacu pada keraton. Bebas dan bertanggung jawab artinya menggarap, mengembangkan secara terbuka dan penuh kreativitas. Dewasa ini seniman Jawa, seperti pengrawit, dalang, dan penari dapat secara bebas menggarap karya seni. Pengrawit yang berkecimpung dalam dunia seni karawitan dapat mengolah berbagai gending yang telah ada dan juga menciptakan gending baru yang dianggap lebih relevan dengan kebutuhan masyarakat dan zaman.

Kata pengrawit dan karawitan dari rawit, berarti halus, lembut, kecil, rumit. Pengrawit berarti orang yang berperan menyajikan komposisi gending secara halus/ lembut dengan menggunakan gamelan sebagai instrumennya. Sementara itu, karawitan merupakan jenis kesenian yang penuh dengan aturan/wewaton dan diolah secara rumit, halus, indah, mengalir tanpa gejolak atas dasar estetika dan etika, serta dipelihara, dipupuk, dijaga kelestariannya (hlm.1--2).

Seorang pengrawit biasanya ahli dalam memainkan alat musik gamelan tertentu, seperti rebab, gender, dan kendang serta ahli perihal komposisi gending. Pengrawit secara sederhana dapat diidentikan dengan nayaga (penabuh gamelan). Dalam budaya Jawa, untuk menyebut orang yang ahli dalam bidang tertentu, sering digunakan kata етри, misalnya етри keris, етри karawitan, dan empu gamelan.

Sebutan empu ditujukan kepada seorang pengrawit yang andal, dapat memainkan beberapa instrumen dalam berbagai perangkat gamelan dengan kualitas sangat baik dalam ensambel, banyak pengalaman, berwawasan luas tentang kebudayaan, khususnya kebudayaan Jawa, serta menjadi anutan bagi masyarakat pendukungnya (hlm.3).

Seiring dengan lunturnya pusat-pusat kekuasaan di Jawa, berkembanglah jenis kesenian di luar tembok keraton, yang pada dekade berikutnya mempengaruhi kesenian di dalam keraton. Bila di dalam keraton tidak ada kegiatan, para abdi dalem pengrawit kraton belajar karawitan di luar keraton. Karawitan di luar tembok keraton dirasa sederhana, kadang-kadang kasar dan monoton. Karawitan di luar tembok keraton setelah mendapat sentuhan para pengrawit dalam keraton terasa menjadi lebih halus, indah, ngrawit, dan bermutu tinggi.

Pembahasan pada buku ini mengenai dua tokoh pengrawit luar tembok keraton, yaitu Cokrodiharjo dan Sunarto Cipto Suwarso difokuskan pada keahliannya dalam seni pengrawit unggulan. Cokrodiharjo merupakan 
penyaji gending, pelatih, komposer gending, serta sebagai pengrawit gender dan kendang; sedangkan Sunarto Cipto Suwarso sebagai penyaji gending, pelatih, komposer gending, serta pengrawit bonang dan rebab. Pengrawit luar tembok keraton tidak hanya dua tokoh, seperti yang diketengahkan oleh Darsono tersebut, sebenarnya masih banyak pengrawit yang handal dan berbobot yang masih hidup seiring dengan tumbuh dan berkembangnya seni karawitan, pedalangan dan perwayangan, baik pada dekade orde lama maupun orde baru. Karawitan, pedalangan dan perwayangan seakan tak terpisahkan. Hampir setiap paguyuban karawitan dapat menyelenggarakan pentas wayang kulit sehingga wajarlah bahwa dua nama tokoh pengrawit dalam buku ini sering mengiringi pentas wayang kulit di tempat-tempat tertentu di Jawa Tengah dan Jawa Timur.

Daerah bekas karesidenan Surakarta, yang terdiri dari kabupaten Klaten, Boyolali, Sragen, Karang Anyar, Sukoharjo, Wonogiri, dan Kodya Surakarta (Solo), merupakan gudang para seniman karawitan (pengrawit). Hampir di setiap kecamatan terdapat perkumpulan karawitan dan di antara mereka yang menggeluti dunia karawitan itu, dapat ditemukan sejumlah pengrawit yang andal. Darsono tepat memilih kedua pengrawit tersebut sebagai tokoh yang pantas untuk mendapatkan perhatian sebagai objek penelitian. Di samping dari segi kualitas mampu memainkan beberapa alat musik, seperti rebab, gender, bonang, dan kendang, mereka juga menjadi pelatih serta produktif dalam menciptakan komposisi gending karawitan. Idealnya banyak peneliti lain membahas biografi seniman kedaerahan, terutama seniman Jawa.

Sebagai sebuah bahasan otobiografis pengrawit, buku ini banyak memberikan informasi tentang kreativitas seni yang dilakukan oleh para pengrawit Jawa, khususnya di daerah Surakarta, baik sebagai penyaji komposisi, pelatih, maupun pencipta gending. Namun, sebagai sebuah kajian budaya buku ini kiranya perlu dikembangkan dengan membahas aspek lain: masalah sosial ekonomis, bahkan ideologi politis jika ada kaitannya dengan karawitan. Misalnya membahas kedudukan dan fungsi para pengrawit di dalam masyarakat; bagaimana kehidupan serta penghidupan sebagai seniman; dan ideologi politis mereka sebagai anak bangsa.

Darmoko

Pengajar PS Jawa,

Fakultas Ilmu Pengetahuan Budaya

Universitas Indonesia 